Covered in: ERIH PLUS, HeinOnline, CEEOL, Index Copernicus, CrossRef, CrossCheck, J-GATE, Google Scholar, Ideas RePeC, Econpapers, Socionet, KVK, WorldCat.

\section{Audit of Forest Restitution Process. Some Findings Regarding the Romanian Space in the Post-Communist Stage}

\author{
Cristina Mihaela LAZĂR ${ }^{1}$, \\ Ioan HURJUI ${ }^{2}$, \\ Nicoleta ASALOŞ3, \\ Ionel BOSTAN ${ }^{4}$ \\ ${ }^{1}$ Faculty of Economic Sciences, \\ Ovidius University, Universității 1, \\ Constanța 900527, Romania, \\ lazarcristinam@yahoo.com
}

${ }^{2}$ Faculty of Economic Sciences and Public Administration, Stefan cel Mare University, Universității 13, Suceava 720229 Romania, ioanhurjui@seap.usv.ro

${ }^{3}$ Faculty of Economic Sciences, Ovidius University, Universității 1, Constanța 900527, Romania, nasalos20@gmail.com

${ }^{4}$ Faculty of Law and Administrative Sciences, Stefan cel Mare University, Universității 13, Suceava 720229 Romania,ionel_bostan@yahoo.com or ionel.bostan@ffdsa.usv.ro
Abstract: This paper takes up a highly important topic, both for the environment and for the domestic economy, by resorting to the performance audit method applied to a component of the activity developed in the forestry sector. We have basically set out to emphasize the weaknesses that have long been present here, in relation to the forest retrocession process and with specific focus on the occurring causes and consequences. On the other hand, we have tried to identify certain ways to bring about the long needed recovery. The scientific background has been set by resorting to the most significant academic research in the field, textbooks and audit standards, reports of the Court of Accounts, regulations, etc. by taking into account the statistical data and the information confirmed by prestigious state organisations/ institutions.

Keywords: forest economics; external audit; deforestation; retrocession; juridical flaws.

How to cite: Lazar, C.M., Hurjui, I., Asalos, N., \& Bostan, I. (2019). Audit of Forest Restitution Process. Some Findings Regarding the Romanian Space in the Post-Communist Stage. Logos Universality Mentality Education Novelty: Law, 7(2), 66-79. doi:10.18662/lumenlaw/28 


\section{Preliminary viewpoints}

Forests are particularly important for economic and social life, if we were to consider the fact that 1.6 billion people are directly dependent upon these resources in order to meet their needs (Bucătaru-Sava, 2012; Urs, 2013); more than 2 billion people benefit from bio fuel for cooking and heating their dwellings etc. (Mery, Alfaro, Kanninen, \& Lobovikov, 2005), while the workforce engaged in the forestry sector amounts to over 12 million people worldwide (FAO, 2007). However, forests currently cover less than $1 / 3$ of the earth's land surface, and their surface is constantly decreasing, as the global deforestation rate rate being around 7.3 million hectares per year (Bradford, 2018). The deforestations taking place, particularly in developing countries (and the conversion of the forest land for farming) account for about $12-15 \%$ of the global CO2 emissions (van der Werf, 2009). As forests play a vital part for life on earth, the issues related to their protection and sustainable management have been closely observed by numerous researchers throughout the world (Joseph et al., 2009; Jha \& Bawa, 2006; Martinez, 1998; Devillez, Duran, \& Renson, 1999; Hansen, Stehman, \& Potapov, 2010). The warning signals that have been triggered ahow that deforestation and forest degradation lead to the shrinkage of the biomass and of the exploitable amoutnof wood, to changes in ecological processes and self-adjusting mechanisms, as well as to the diminishing of biodiversity (Rodgers, 1997). Romania is endowed with a wide forest variety (Figure 1) and is one of the few European countries whose territories still foster virgin forests, that amount to about 250 thousand hectares (MARD, 2013: 34-35). 


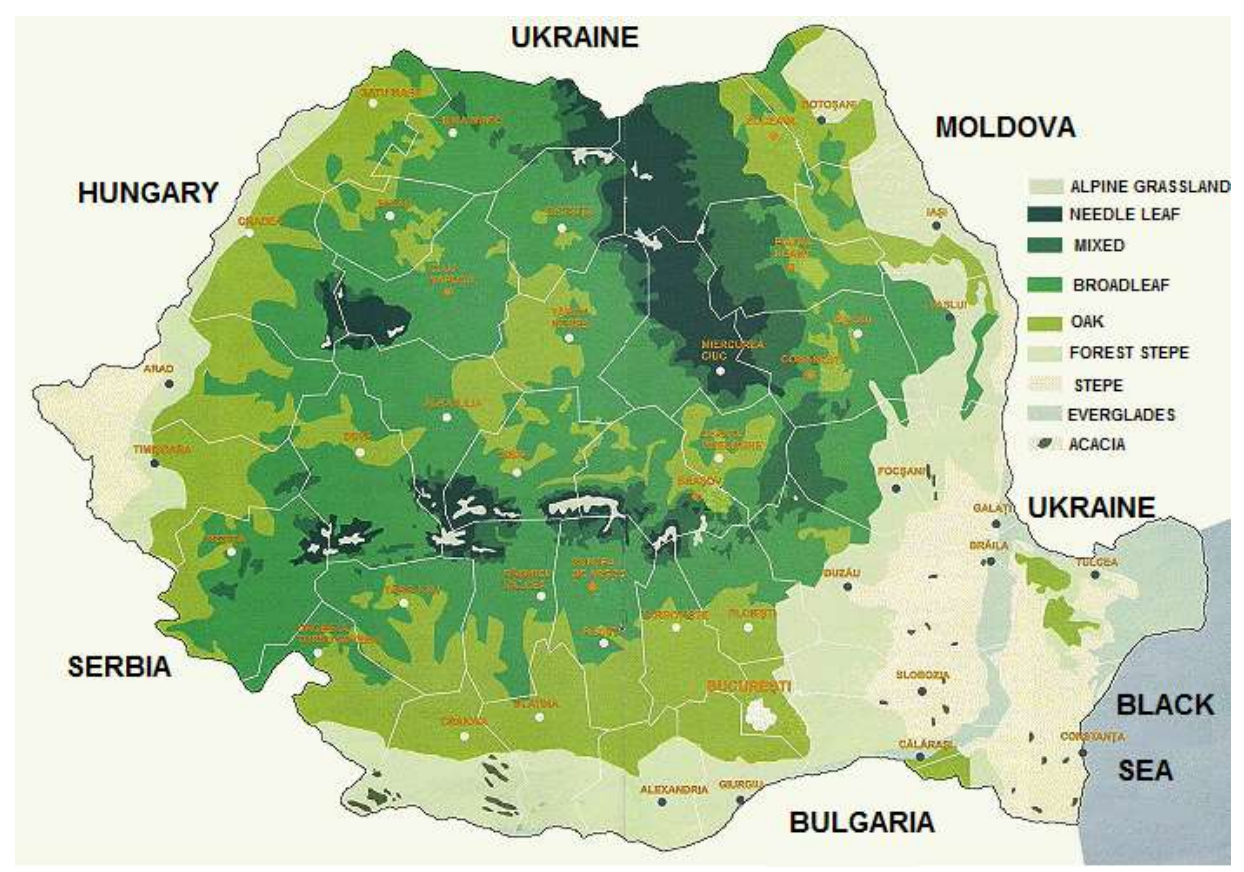

Figure 1. Map of forests in Romania

Source: "Harta pădurilor..." (n.d.)

The national forestry fund includes (in the year 2017) a total area of 6565 thousand hectares, of which the forest area is 6406 thousand hectares, respectively. $1 / 3$ of the country's surface, being relatively stable over the last five years (NIS, 2018). The resinous species cover 1924 thousand hectares $(30.0 \%)$, and the hardwoods, in turn, occupy 4482 thousand hectares (70.0\% respectively) (Marin, 2010); the surface of the forest vegetation outside the national forest land amounts to approx. 350 thousand hectares.

In 2017 a volume of wood was harvested at 18316 thousand cubic metres, 5.0\% lower than in 2013 (Figure 2). 


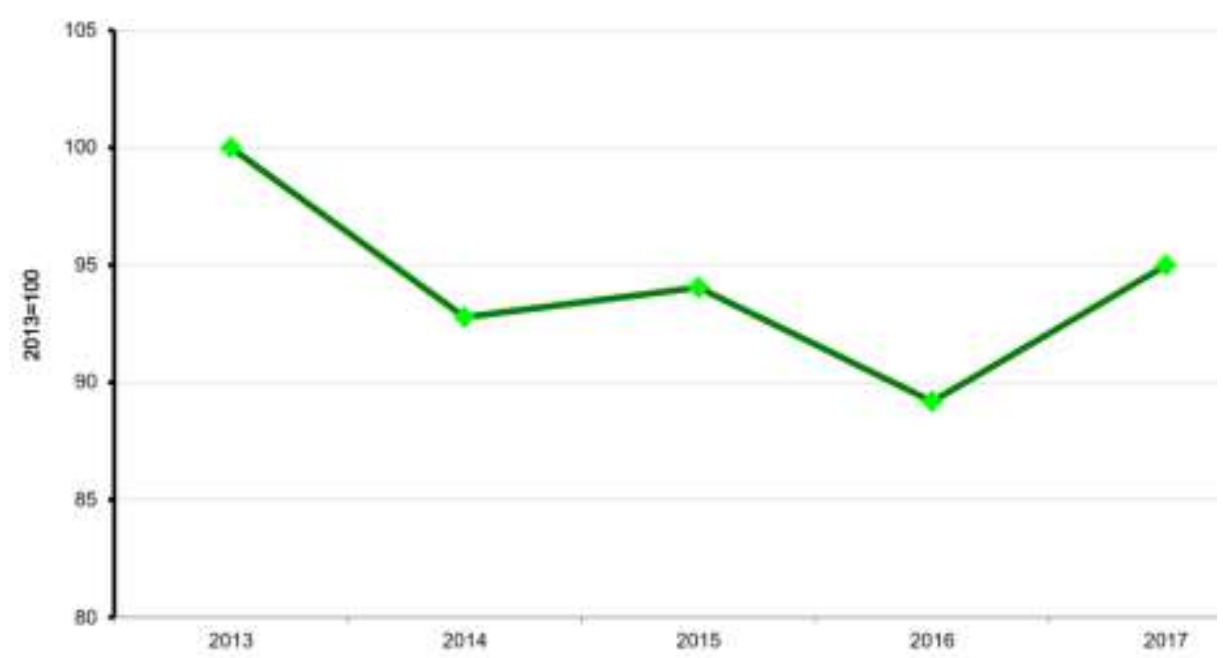

Figure 2. Dynamics of wood mass harvesting (2013 - 2017)

(NIS, 2018)

Of the total harvested volume, the beans and the beech constitute each one third of the total harvested volume, and the beech, oak and various hard and soft species are altogether another third. Referring to the surface area of the state-owned forest fund, managed by ROMSILVA (The National Forest Administration), this is 3189 thousand hectares, lands covered with forest representing approx. 99\%. Of these, 1/3 returns the beech, 1/4 resinous, $1 / 5$ - oak, etc. (NIS, 2018). Concerns in terms of forest sustainable management are numerous in Romania as well, as proved by several scientific research papers in the field (Bouriaud, 2008; Coandă \& Stoiculescu, 2005; Dănescu, Costache, \& Mihăilă, 2010; Doniță \& Soran, 1994; Măciucă \& Lupăştean, 2004). Forest economics is seen as a multiple function branch, but two aspects should become the objectives of specific development projects (CPPPDA, 2013: 38-39). These are (1) expanding the forests by planting new trees and (2) rational exploitation of forest resources. The situation is far from simple, if we were to take into account the fact that people believe forests to be a general benefit (biodiversity, climate, soil protection, water protection, etc.), while owners are interested in exploitability (RCA, 2013a).

However, establishing the balance is quite a difficult matter which depends on the development of societies and also entails that the state should take over certain administration costs. Under these circumstances, as concerns the issues related to the complex process of forest retrocession, which has been enforced as a restoring act after 1990, mainly as a 
consequence of the forests having been publicly owned after 1948, we wish to use the instruments of performance audit to reveal the difficulties encountered in the analysed field and try to make certain suggestions means to lead to a visibly increased efficiency.

\section{Materials and Methods}

The present work uses published information primarily from FAO, ECA, GR, NIS, ROMSILVA, RCA, etc. and other regional level/localspecific case studies. Our investigation focuses on the period during 19902010, the data and information that have been used are public, and their validity is guaranteed by their presence in various scientific papers published under the aegis of prestigious public organisations/institutions. The analyses and correlations drawn by the authors have taken into account the latest editions of the journals published by these institutions, mainly consisting of statistical papers, standards, procedural guidebooks, reports (RCA, 2013a; RCA, 2013b; ECA, 2008). The rigorous and scientific nature of the audit is visible in the relatively recent papers of several renown specialists in the field (Carmichael, Willingham, \& Schaeller, 1996; Boulescu, Ghiţă, \& Mareş, 2001; Loebbecke, 2003; Goodwin, 2004; Willekens, 2005; Cosserat, 2005; Dănescu, 2007; Fraser \& Chris, 2009), by taking into account the European context. The activity of ROMSILVA - that is in charge with the management of the state forest land - is periodically subject to performance audit conducted by RCA, as Supreme Audit Institution (Boulescu, Ispir, Dascălu, 2009; Dascălu \& Nicolae, 2006; Bostan, 2010a, $2010 \mathrm{~b}, 2011)$, as is the case of other national bodies that currently manage substantial state resources, and the respective reports and summaries are posted on the RCA website in due time.

The audit activities entail procedures that are exclusively in compliance with the international audit standards and with the best practices in the field. The audit criteria have been selected through the use of professional reasoning and have been extracted from the current normative framework (RP, 1990, 2005, 2008; GR, 2008, 2009a, 2009b).

\section{Results and discussion}

The activity of ROMSILVA is governed by the Ministry of the Environment and Climate Change (MECC). Its purpose is the sustainable and unitary management of the publicly owned forest land in order to augment the forests' role in the improvement of the environment conditions and in providing the domestic economy with specific goods and services 
(GR, 2009a, 2009b). It further coordinates and implements the national programme for the equine genetic alleviation. It is also in charge with the administration of 23 national and natural reserves where the publicly owned forest land has a significant weight, ensuring biodiversity in these protected areas (ROMSILVA, 2014). The enforcement of the sustainable management principle in European countries entails the fact that forest ownership rights should not be considered as an absolute right, as the balance between the general interest of the community and the owner's private interests should be governed by the law; up to a certain extent, the Romanian legal standards do take this aspect into account (RP, 1990, 2000, 2005). The changes in ownership rights - in terms of the retrocession occurring after 1990, after the enforced state ownership of the forests in 1948 (Kuemmerle et al., 2012) - are quite topical in terms of the integrity and the development of the forest land surface, since the new categories of owners have various attitudes concerning the preservation of the forest use and/or with the possibility to expand it. Here is how the situation evolved (RCA, 2013a) in the context we are concerned with. At the end of 1990, the surface of the forest land was of 6367.66 thousand hectares, of which the forests' surface was 6248.99 thousand hectares and that of other land was of 118.67 thousand hectares. The surface of the forest land at the end of 2010 was of 6515.17 thousand hectares, of which publicly owned 4363 thousand hectares and privately owned 2152.17 thousand hectares. The publicly owned surface amounted to 3338.90 thousand hectares, of which 3224.95 thousand hectares were actually forest covered, while 113.95 thousand hectares - other land. During 1990-2010, the surface of the publicly owned forest land diminished by about 3000 thousand hectares, through retrocession to legal and natural persons, after the enforcement of the land fund laws.

The retrocession laws (RP, 1990, 2000, 2005), were rather confusing and lacking in vision and have thus given rise to abuse, conflicts and disputes etc., and often extended the restoration process of the ownership rights (in Table 1 we have presented the status of the restoration of ownership rights as concerns the forest covered land), thus endangering the stability of the forest system and of the timber market. 
Table 1. State of the restoration of ownership rights over forest covered land (RCA, 2013a)

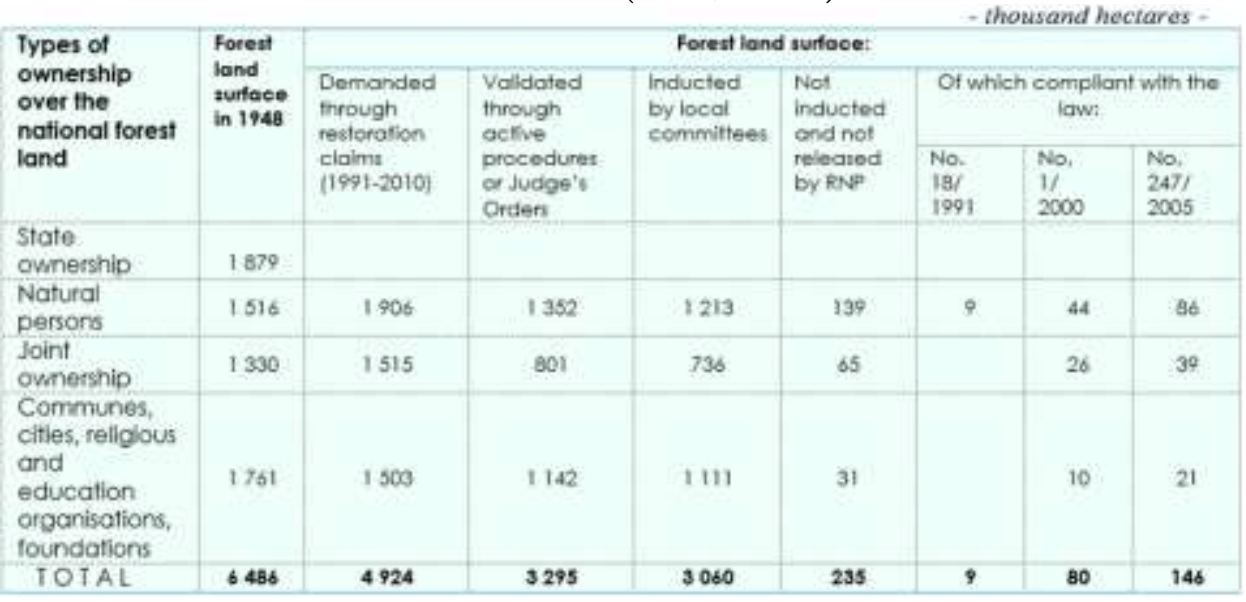

As can be noted, the forest land claims made by natural persons exceed the forest land surface owned at the end of 1948 by 390 thousand hectares, and if we were to include joint ownership, apart from natural persons, their claims exceed the said surface by 575 thousand hectares.

According to the calculations of the Romanian Court of Audit, a surface of about 561.17 thousand hectares has been reclaimed or is in various stages of the administrative or juridical retrocession process, without meeting the criteria established by the law (in Table 2 you will find a summary of the juridical flaws), and have been classified as litigious cases. 
Audit of Forest Restitution Process. Some Findings Regarding the Romanian ... Cristina Mihaela LAZĂR et al.

Table 2. Juridical flaws in the claims for the restoration of ownership rights over forest land (in terms of the subject of the claim, claimant and ways in which the claim has been justified)

\begin{tabular}{|c|c|c|}
\hline Subject of the claim & Claimant & $\begin{array}{l}\text { (In)consistency of the } \\
\text { claim }\end{array}$ \\
\hline 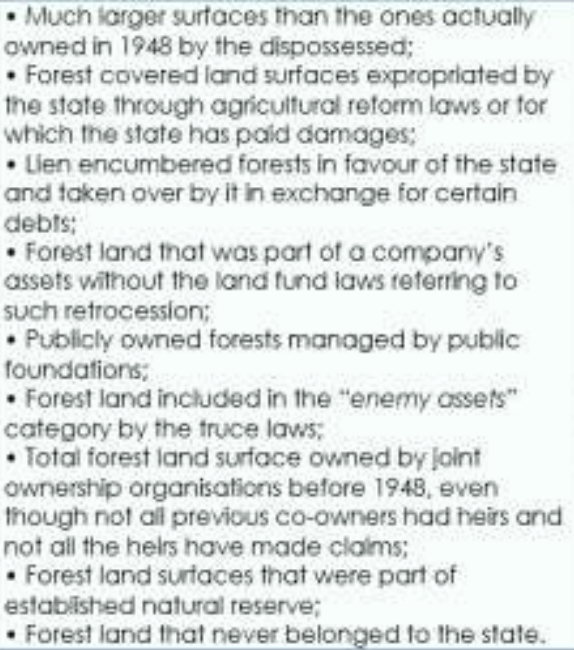 & $\begin{array}{l}\text { - Indlviduals deptlved of } \\
\text { inheritance rights; } \\
\text { - Uniawful or contested } \\
\text { representatives of } \\
\text { cerfain joint ownership } \\
\text { types; } \\
\text { - Joht ownership types } \\
\text { that are not or cannot } \\
\text { continue to have the } \\
\text { tights and obligations of } \\
\text { legal persons / business } \\
\text { organisations; } \\
\text { - Provies holding } \\
\text { mandates whose } \\
\text { outhenticity cannot be } \\
\text { verified since they have } \\
\text { been issues abroad; elc. } \\
\text { - Relligious organisations } \\
\text { that have used but not } \\
\text { owned forest land. }\end{array}$ & $\begin{array}{l}\text { - Claims that were not } \\
\text { backed by documents } \\
\text { showing ownership rights } \\
\text { and requiring witness } \\
\text { testimonies and extro. } \\
\text { judiclal examinations; } \\
\text { - Deeds than could not } \\
\text { be considered } \\
\text { ownership rights: } \\
\text { - Old and irrelevant } \\
\text { documents (since the } \\
\text { pieces of land have } \\
\text { often undergone } \\
\text { signilicant changes and } \\
\text { so the forest land surface } \\
\text { owned by the } \\
\text { dispossessed claimants in } \\
1948 \text { was much smaller } \\
\text { or did not exist } \\
\text { anymore). }\end{array}$ \\
\hline
\end{tabular}

If all the said claims were to be granted, the forest land surface owned by the state would be much smaller than the one held in 1948, even though certain objective elements should prevent this from happening. And this, all the more so as the law confines the categories of individuals entitled to restoration, and, on the other hand, the restoration of the ownership rights of those individuals entitled to make claims, which also means the acknowledgement of the inheritance, but certain people have not made such claims. Subsequently, a number of legacies have thus inevitably remained vacant.

The abusive restorations of ownership rights (Ignătescu, 2013) over forest land amount to about $10 \%$ of the surfaces already instituted or about to be instituted (RCA, 2013a), at the end of 2012, while 983 litigious cases in various stages were being tried in law courts, claiming the restoration of ownership rights over forest land surfaces amounting to 660 thousand hectares. However, even if it's absolutely legal, the retrocession of ownership rights over forest land surfaces leads to excessive breakage, thus hindering the unitary and efficient implementation of sustainable management policies for forest resources in Romania (ECA, 2008), in line with the European trends (European Commission, 2010). A significant risk that may occur is 
the slow cessation of mountain forests clearance, thus leading to a more accentuated frequency of floods, by accelerating the slope runoff of the water from torrential rains towards catchments.

\section{Conclusions and recommendations}

The law on forest control and management has been separated from the one referring to the restoration of ownership rights, thus triggering negative effects on the publicly owned forest land surfaces. What remains to be done now is for the Ministry of Public Finance (MPF), as representative of the Romanian government and the MECC, in charge of forestry activities, to take immediate measures and give solutions for the closure/completion of the restoration/retrocession of publicly owned forest land surfaces. On the other hand, the MPF should take action to restore the ceded forest land surfaces to the state, given the juridical flaws presented above.

A recommended course of action would be to hire the services of law firms to represent the interests of the Romanian government in order to stop the abuse and illegal actions that would lead to the further illegal retrocession of other land surfaces.

It would be equally important to organise an inter-ministry committee (with members from the MPF, the MECC, the Ministry of Internal Affairs, the Ministry of Justice and the Ministry of Regional Development), that would analyse the history and the legal status of the large forest properties during 1920-1990, so as to develop a solid documentation to be filed and to support the complex cases tried in law courts or to be launched in order to compensate the government.

\section{Acknowledgments}

The authors would like to thank the anonymous reviewers for their valuable comments and suggestions to improve the quality of the paper.

Conflicts of Interest: The authors declare no conflict of interest.

\section{References}

Bostan, I. (2010a). Auditul public extern [External public audit]. Bucharest, Romania: Univers Juridic.

Bostan, I. (2010b). Proceduri privind auditul public financiar și al performanţei [Procedures regarding public financial and performance audit]. Iaşi, Romania: TipoMoldova. 
Audit of Forest Restitution Process. Some Findings Regarding the Romanian ... Cristina Mihaela LAZĂR et al.

Bostan, I. (2011). Institutional metamorphoses regarding the exercise of external public audit in Romania. Theoretical and Applied Economics, XVIII, 12(565), 33-42.

Boulescu, M., Ghiță, M., \& Mareş, V. (2001). Fundamentele auditului [Audit fundamentals]. Bucharest, Romania: Economica.

Boulescu, M., Ispir, O., \& Dascălu, E. D. (2009). Uniunea Europeană - Instituții, buget, audit [European Union - Institutions, budget, audit]. Bucharest, Romania: Didactică si Pedagogică.

Bouriaud, L. (2008). Proprietatea şi dreptul de proprietate asupra pădurilor, între reconstituire şi re-compunere [Property and ownership of forests, between reconstruction and re-composition]. Analele Universitătii "Ştefan Cel Mare" Suceava. Secțiunea Silvicultură, Serie nouă, 2. Retrieved from http://www.silvic.usv.ro/anale/as_2008_2/as_bouriaud_2008_2.pdf

Bradford, A. (2018). Deforestation: Facts, causes and effects. Retrieved from https://www.livescience.com/27692-deforestation.html

Bucătaru-Sava, A. M. (2012). Research on diversity producers of beech ecosystems and mixed beech-conifers forests, from Ciucas Massif. Ph.D. Thesis. Braşov, Romania: Transivania University.

Carmichael, D. R., Willingham, J. J., \& Schaeller, C. A. (1996). Auditing concepts and methods: A guide to current theory and practice. New York, USA: McGraw-Hill.

Coandă, C., \& Stoiculescu, C. D. (2005). Cercetări asupra biodiversității forestiere din unele arii protejate din Carpații României [Research on forest biodiversity in some protected areas in the Romanian Carpathians]. Revista Pădurilor, 5, 32-35.

Comisia Prezidențială pentru Politici Publice de Dezvoltare a Agriculturii (CPPPDA). (2013). Cadrul național strategic rural (2014-2020) [National rural strategic framework (2014-2020)]. Bucharest, Romania: Romanian Presidency.

Cosserat, G. W. (2005). Modern auditing (2nd ed.). Hoboken, USA: John Wiley \& Sons Ltd.

Dănescu, F., Costache, I., \& Mihăilă, E. (2010). Sistematica stațiunilor forestiere [Systematics of forest resorts]. Bucharest, Romania: Silvica.

Dănescu, T. (2007). Audit financiar - convergențe între teorie și practică [Financial audit convergence between theory and practice]. Bucharest, Romania: IRECSON Publishing House.

Dascălu, E. D., \& Nicolae, F. (2006). Internal audit in public institutions. Bucharest, Romania: Economică.

Devillez, F., Duran, V., \& Renson, Y. (1999). Estimation de la valeur ecologique de la vegetation forestiere et des haies: Application aux etudes d'incidence 
[Estimation of the ecological value of forest vegetation and hedges: Application on studies of incidence]. Belgian Journal of Botany, 1(128).

Doniţă, N., \& Soran, V. (1994). Din problematica generată privind biodiversitatea şi implicațiile acestei probleme în silvicultură [From the issues generated regarding biodiversity and the implications of this problem in forestry]. Revista Pădurilor, 109(4), 6-9. Retrieved from http://revistapadurilor.com/wp-content/uploads/2017/06/RevistaPadurilor-nr-4-1994.pdf

European Commission. (2010). Green paper on forest protection and information in the EU: Preparing forests for climate change SEC(2010)163 final. Retrieved from http://www.europarl.europa.eu/meetdocs/2009_2014/documents/com/c om_com\%282010\%290066_/com_com\%282010\%290066_en.pdf

European Court of Accounts (ECA). (2008). Special report no. 8 - Support for the improvement of the economic value of forests from the European agricultural fund for rural development. Retrieved from http://www.eca.europa.eu/Lists/ECADocuments/SR13_08/SR13_08_E N.pdf

Food and Agriculture Organization of the United Nations (FAO). (2007). State of the World's forests. Retrieved from ftp://ftp.fao.org/docrep/fao/009/a0773e/a0773e09.pdf

Fraser, I., \& Chris, P. (2009). The future of the external audit function. Managerial Auditing Journal, 24(2), 104-113. doi:10.1108/02686900910924536

Goodwin, J. (2004). A comparison of internal audit in the private and public sectors. Managerial Auditing Journal, 19(5), 640-650. doi:10.1108/02686900410537766

Government of Romania (GR), Ministry of Environment, Water and Forests. (2008). Programul național de împădurire. Retrieved from http://www.mmediu.ro/paduri/informatii/Programul-NationalImpadurire.pdf

Government of Romania (GR). (2009a). Hotărârea de Guvern nr. 229/2009 privind reorganizarea Regiei Naționale a Pădurilor - Romsilva și aprobarea regulamentului de organizare și funcționare. Monitorul Oficial al României, 162, 2009, March 16.

Government of Romania (GR). (2009b). Hotărârea de Guvern nr. 1635/2009 privind organizarea și funcționarea Ministerului Mediului și Pădurilor. Monitorul Oficial al României, 22, 2010, January 12.

Hansen, M. C., Stehman, S. V., \& Potapov, P. V. (2010). Quantification of global gross forest cover loss. Proceedings of the National Academy of Sciences, 107(9), 8650-8655. doi:10.1073/pnas.0912668107 
Audit of Forest Restitution Process. Some Findings Regarding the Romanian ... Cristina Mihaela LAZĂR et al.

Harta pădurilor din România [Map of forests in Romania]. (n.d.). Retrieved from http:/ / www.profudegeogra.eu/harta-padurilor-din-romania

Ignătescu, C. (2013). Abuzul de drept [Abuse of rights]. Iaşi, Romania: Lumen.

Jha, S., \& Bawa, K. S. (2006). Population growth, human development, and deforestation in biodiversity hotspots. Conservation Biology, 20(3), 906-912. doi:10.1111/j.1523-1739.2006.00398.x

Joseph, S., Blackburn, G. A., Gharai, B., Sudhakar, S., Thomas, A. P., \& Murthy, M. S. R. (2009). Monitoring conservation effectiveness in a global biodiversity hotspot: the contribution of land cover change assessment. Environmental Monitoring and Assessment, 158(1-4), 169-179. doi:10.1007/s10661-008-05714

Kuemmerle, K. T., Radeloff, V. C., Szabo, A., Mîndrescu, M., Keeton, W. S., Abrudan, I. V., Griffiths, P., Gancz, V., \& Hostert, P. (2012). Forest restitution and the protected area effectiveness in post-socialist Romania. Biological Conservation, 146(1), 204-212. doi:10.1016/j.biocon.2011.12.020

Loebbecke, A. A. (2003). Audit. O abordare integrată [Audit. An integrated approach]. Chişinău, Republic of Moldova: ARC.

Măciucă, A., \& Lupăştean, D. (2004). Considerații relative la procesul de stabilire a indicatorilor pentru evaluarea biodiversității forestiere. Analele Universității "Ştefan cel Mare" Suceava, Secţiunea Silvicultură, 2, 141-146. Retrieved from http://www.silvic.usv.ro/anale/as 2004 2/as maciuca lupastean 20042 .pdf

Marin, G. (2010). Pădurile şi silvicultura din România [Forests and forestry in Romania]. Bucharest, Romania : ICAS. retrieved from http://www.fao.org/fileadmin/user_upload/Europe/documents/Events_ 2010/For_GP/Romania_Mar_ro.pdf

Martinez, K. E. (1998). Social determinants of deforestation in developing countries: A cross-national study. Social Forces, 77(2), 567-586. doi: $10.2307 / 3005539$

Mery, G., Alfaro, R. I., Kanninen, M., \& Lobovikov, M. (2005). Changing paradigms in forestry: Repercussions for people and nature. In G. Mery, R. Alfaro, M. Kanninen \& M. Lobovikov (Eds.), Forests in the global balance - Changing paradigms (pp. 13-20). Vienna, Austria: International Union of Forest Research Organizations. Retrieved from https://www.iufro.org/fileadmin/material/science/spps/wfse/wfse-achieartic-01.pdf

Ministry of Agriculture and Rural Development (MARD). (2013). Analiza socioeconomică în perspectiva dezvoltării rurale (2014-2020) [Socio-economic analysis in the perspective of rural development (2014-2020)]. Retrieved from http://www.madr.ro/docs/dezvoltare-rurala/programare-20142020/analiza-dezvoltarii-rurale-agricultura-iulie-2013.pdf 
National Institute of Statistics (NIS). (2018). Statistica activităţilor din silvicultură în anul 2017 [Statistics of forestry activities in 2017]. Retrieved from http://www.insse.ro/cms/sites/default/files/field/publicatii/statistica_act ivitatilor_din_silvicultura_in_anul_2017_0.pdf

Rodgers, W. A. (1997). Patterns of loss forests biodiversity - A global perspective. Proceedings of the XI World Forestry Congress, II, 1997, October 13-22. Antalya, Turkey.

Romanian Court of Accounts (RCA). (2013a). Raport de audit privind situaţia patrimonială a fondului forestier din România (1990-2012) [Audit report on the patrimonial situation of the forestry fund in Romania (1990-2012)]. Retrieved from http://cursdeguvernare.ro/wpcontent/uploads/2013/04/Raportfondforestier_1990_2012.pdf

Romanian Court of Accounts (RCA). (2013b). Manual privind auditul performanței [Handbook on Performance Auditing]. Retrieved from http://www.curteadeconturi.ro/sites/ccr/RO/Control\%20si\%20Audit/D ocumente/AP\%20interior-BT-\%20lnk.pdf

Romanian Parliament (RP). (1990). Legea nr.18/1991 a fondului funciar [Law no. 18/1991 of the land fund]. Monitorul Oficial al României, 1, 1998, January 05.

Romanian Parliament (RP). (2000). Legea nr. 1/2000 pentru reconstituirea dreptului de proprietate asupra terenurilor agricole și celor forestiere, solicitate potrivit prevederilor Legii fondului funciar nr. 18/1991 și ale Legii nr. 169/1997 pentru modificarea și completarea Legii fondului funciar nr. 18/1991 [Law no. 1/2000 for the reconstruction of the property right on agricultural and forest land, required according to the provisions of the Law of the land fund no. 18/1991 and of Law no. $169 / 1997$ for amending and supplementing the Law of the land fund no. 18/1991]. Monitorul Oficial al României, 8, 2000, January 12.

Romanian Parliament (RP). (2005). Legea nr. 247/2005 privind reforma în domeniile proprietății și justiției precum și unele măsuri adiacente [Law no.247 on reform in the fields of property and justice as well as some adjacent measures]. Monitorul Oficial al României, 381, 2007, June 06.

Romanian Parliament (RP). (2008). Legea nr. 46/2008 privind Codul silvic al României [Law no. 46/2008 regarding the Forest Code of Romania]. Monitorul Oficial al României, 611, 2015, August 12.

ROMSILVA (2013). Report. Retrieved from http://www.rosilva.ro/articole/prezentare_generala_p_178.htm

Urs, V. (2013). Rolul şi importanţa pădurilor. Agricultura românească [The role and importance of forests. Romanian agriculture]. Retrieved from http://www.agriculturaromaneasca.ro/produse/rolul-i-importanapdurilor-197-c5.html 
Audit of Forest Restitution Process. Some Findings Regarding the Romanian ... Cristina Mihaela LAZĂR et al.

Van der Werf, G. R., Morton, D. C., DeFries, R. S., Olivier, J. G. J., Kasibhatla, P. S., Jackson, R. B., Collatz, G. J., \& Randerson, J. T. (2009). CO2 emissions from forest loss. Nature Geoscience, 2(11), 737-738. doi:10.1038/ngeo671

Willekens, M. (2005). Audit risk. In Encyclopedic of Accounting (pp. 63-66). Hoboken, USA: Blackwell. 